\title{
RESEARCH NOTE \\ Implementation of an in vitro bioassay as an indicator of the bionutrient FitoMas E
}

\author{
María Elena Díaz de Villegas¹, Grizel Delgado¹, Mauricio Rivas², Esmérida \\ Torres $^{1}$, and Maribel Saura ${ }^{1}$ \\ 'Departamento Bioquímica, Instituto Cubano de Investigaciones de los derivados de la Caña de Azúcar \\ (ICIDCA). Vía blanca No 804 y Carretera Central, San Miguel del Padrón. Ciudad Habana, Cuba. \\ ${ }^{2}$ Departamento Matemática Aplicada, Instituto Cubano de Investigaciones de los derivados de la Caña de \\ Azúcar (ICIDCA). Vía blanca No 804 y Carretera Central, San Miguel del Padrón. Ciudad Habana, Cuba.
}

\begin{abstract}
M.E. Díaz de Villegas, G. Delgado, M. Rivas, E. Torres, and M. Saura 2011. Implementation of an in vitro bioassay as an indicator of the bionutrient FitoMas E. Cien. Inv. Agr. 38(2): 205-210. Seed bioassays are employed to determine the stimulatory effect of various biological products on the seed germination of plants used for the detection and control of toxic environmental contaminants. The objective of the present study was to design an in vitro bioassay to monitor the quality of the final production of FitoMas E, a bionutrient derived from the sugar industry and produced by the Instituto Cubano de Investigaciones de los derivados de la Caña de Azúcar By-Products (ICIDCA), by determining rates of seed germination and growth of lettuce (Lactuca sativa L.) as an indicator plant. A significant effect of controllable factors under study (FitoMas E concentration in lots and replicates of Petri dishes) was determined by one-way and multifactor ANOVA analysis. In all cases, the highest values of relative germination and growth occurred at a concentration of FitoMas E of $0.1 \mathrm{~mL} \mathrm{~L}^{-1}$, with a marked increase in the growth of hypocotyl (RHG), which decreased at concentrations of 2.5 and $5 \mathrm{~mL} \mathrm{~L}^{-1}$. These results can be explained by the hormesis phenomenon, which is characterized by stimulation at low doses and inhibition at high doses. For a confidence level of $\mathrm{P} \leq 0.05$, there were no significant differences between Petri dishes with lettuce seeds and lots in all responses tested. The bioassay method implemented in this study was fast, simple and reliable.
\end{abstract}

Key words: Bioassay, bionutrient, lettuce seed.

\section{Introduction}

Production of biological products, including bionutrients, for agriculture requires the implementation of chemical and biological methods for quality control, the cluster of properties and characteristics that ensure products or services

Received December 7, 2009. Accepted May 4, 2011. Corresponding author: mariaelena.diaz@icidca.edu.cu are suitable for the needs that they are created for (Fernández-Larrea, 2002).

Traditional chemical methods allow the characterization of raw materials and products obtained. These analyses are complemented by seed bioassays for the detection and control of toxic environmental contaminants, in which the effects of these products on the organisms studied are evaluated (Navarro, 2006; Torres, 2003). 
These bioassays are also used as a tool for evaluating water contamination due to their ability to detect adverse effects of complex chemical mixtures (Bohórquez and Campos, 2007).

Previous studies have demonstrated that seed bioassays can ascertain the stimulatory effect of different biological products as determined by germination percentage indicators, vigor index, hypocotyl length and radicle length in seedlings (Díaz et al., 2002; Keriko et al., 1995).

On the other hand, bioassays are also used to detect phytotoxic metabolites of products used in agriculture, which may have negative effects on plants. For example, a negative effect on plants may occur when compost is applied at an immature stage (Zucconi et al., 1981; Emino and Warman, 2004). This occurs due to different factors including ammonium, volatile organic acid, heavy metal and salt contents (Varnero et al., 2007). At high concentrations, these substances can cause harmful effects on plant development by inhibiting seed germination or root growth. Therefore, the use of these substances on crops is very risky.

Different model species are used in bioassays, including lettuce (Lactuca sativa L.). Lettuce is used due to the high species sensibility, rapid germination, uniform germination, low associated costs, lack of sophisticated equipment and high availability. Moreover, data obtained from the application of this assay are largely representative of the effect on seeds or plantlets in general (Gariglio et al., 2002; Pennachio et al., 2005; Sobrero and Ronco, 2004).

FitoMas $\mathrm{E}$ is a bionutrient derived from the sugar industry and is produced by the Instituto Cubano de Investigaciones de Derivados de la Caña de Azúcar (ICIDCA). It is widely used in agriculture because it has a range of effects, evidenced by an increased vigor and resistance to plague and disease of treated crops, including increases of yield and harvest quality (Montano et al., 2007). Additionally, the safety of this product is supported by a registration certificate in the Central Fertilizers Register of Cuba (No. Ref.025/09).
The main objective of this work was to design an in vitro bioassay with lettuce seeds to monitor the quality of the final FitoMas E product by determining the germination and growth indexes of this indicator plant.

\section{Materials and methods}

Lital VAR 2 lettuce seeds were used (L. sativa), and they were purchased in Empresa de Aseguramiento a la Agricultura of Havana City (Cuba).

Samples from three lots of FitoMas E production were randomly selected using a completely random 3 x 3 factorial experimental design with the following factors: FitoMas E concentrations of $0.1 \mathrm{~mL} \mathrm{~L}^{-1}, 2.5$ and $5 \mathrm{~mL} \mathrm{~L}^{-1}$; and three lots $(1$ - No. 90040; 2 - No. 90060; and 3 - No. 90016).

Twenty lettuce seeds were placed in each Petri dish on filter paper moistened with $2.5 \mathrm{~mL}$ of distilled water, and each treatment was carried out in triplicate. The dishes were placed in a white polyethylene bag, which was placed in an incubator without illumination at a temperature of $27 \pm 2{ }^{\circ} \mathrm{C}$ for $3 \mathrm{~d}$. With this experimental setup, humidity loss was avoided.

The assay was constructed according to the methodology described by Sobrero and Ronco (2004), with some modifications.

Multifactorial variant analysis was performed to determine the assay reproducibility for PRG, RRG, RHG and GI as response variables of the samples treated with $0.1 \mathrm{~mL} \mathrm{~L}^{-1}$ FitoMas E. The Petri dish replicates used in the bioassay, which were subject to the same experimental conditions but different FitoMas E lots, were taken as the factors influencing the responses.

\section{Effect on germination}

After the incubation period (3 days), the number of seeds germinating normally, which was classified by the germination criterion of the appearance of the radicle, was recorded. 
Effect on the radicle and hypocotyl elongation

Once the incubation was complete, the Petri dishes were frozen at $0{ }^{\circ} \mathrm{C}$ to allow measurement of radicle and hypocotyl length (Sobrero and Ronco, 2004). The soft seedlings were placed on a transparent glass plate and were photographed from a distance of $32 \mathrm{~cm}$.

Measurements of radicle and hypocotyl lengths were performed digitally using the Adobe Photoshop (Version 8.0.1) computer program.

\section{Expression of the results}

The stimulators or phytotoxic effects were evaluated according to the following indicators: percentage of relative germination (PRG), relative radicle growth (RRG) and relative hypocotyl growth (RHG).

The germination index (GI) was calculated to determine the FitoMas E concentration at which phytotoxic effects were observed, and calculation of the GI involved the PRG and RRG values (Tiquia, 2000) using the following equations:

\section{Relative germination percentage (PRG)}

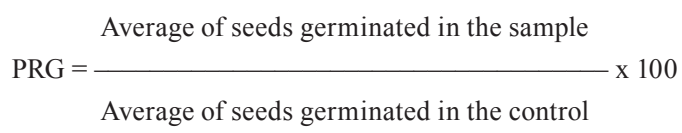

Relative radicle growth ( $R R G$ )

$$
\mathrm{RRG}=\frac{\text { Average radicle length in the sample }}{\text { Average radicle length in the control }}
$$

\section{Relative hypocotyl growth (RHG)}

$$
\mathrm{RHG}=\frac{\text { Average hypocotyl length in the sample }}{\text { Average hypocotyl length in the control }} \times 100
$$

\section{Germination index (GI)}

$$
\mathrm{GI}=\frac{\text { PRG } \times \text { RRG }}{100}
$$

\section{Statistical analysis}

Were used simple and multifactorial analysis of variance (ANOVA) performed for each variable observed (PRG, RRG, RHG and GI) to detect a significant effect from the controllable factors under study (FitoMas E concentration, lots and replicate dishes). Duncan's test was utilized to test multiple ranges. All statistical analyses were performed using the Statgraphics Centurion XV (version 15.2.05) statistical program.

\section{Results}

The effects of the FitoMas E concentrations on PRG, RRG, and RHG are shown in Figure 1. The different letters indicate the results that were statistically different, as determined by ANOVA and the LSD multiple range test at a significance level of $\mathrm{P} \leq 0.05$.

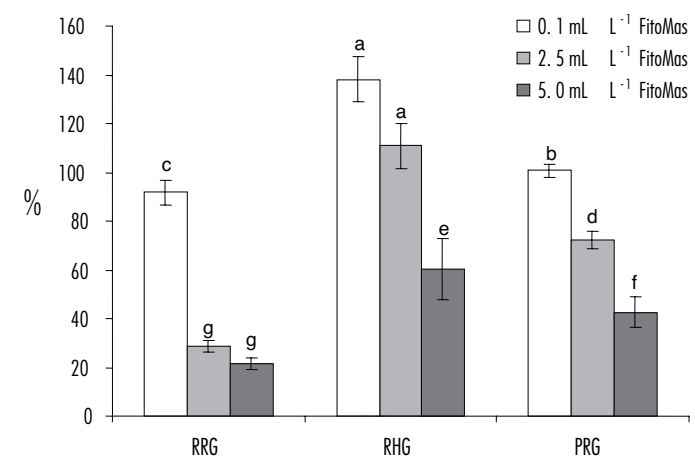

Figure 1. Influence of different concentrations of FitoMas $\mathrm{E}$ on Percentage relative germination percentage (PRG), relative radicle growth (RRG) and relative hypocotyl growth (RHG) of Lactuca sativa seeds. Standard errors are indicated for each bar. Bars with the same letter are not statistically different $(\mathrm{P} \leq 0.05)$.

The highest relative germination and growth values in each case were reached at a FitoMas E concentration of $0.1 \mathrm{~mL} \mathrm{~L}^{-1}$, which resulted in significant differences for all the responses ana- 
lyzed (PRG, RRG and RHG) in relation to the differences obtained with the other concentrations evaluated. A significant increase in the hypocotyl growth (RHG) was observed, with a maximum value close to $140 \%$ at FitoMas E concentration of $0.1 \mathrm{~mL} \mathrm{~L}^{-1}$.

Although to a lesser extent, the stimulation effect on RHG was also observed at a concentration of $2.5 \mathrm{~mL} \mathrm{~L}^{-1}$; however, a significant inhibitory effect of germination and growth occurred at a higher dose $\left(5 \mathrm{~mL} \mathrm{~L}^{-1}\right)$.

Figure 1 shows that a significantly negative influence on PRG was observed as the FitoMas E concentration was increased to 2.5 and $5 \mathrm{~mL} \mathrm{~L}^{-1}$, and this effect was even more pronounced in the case of RRG.

Figure 2 shows that the GI was $90 \%$ at a FitoMas E concentration of $0.1 \mathrm{~mL} \mathrm{~L}^{-1}$ and that there was a significant decrease in the GI with FitoMas E concentrations of 2.5 and $5 \mathrm{~mL} \mathrm{~L}^{-1}$, resulting in GI values lower than $20 \%$.

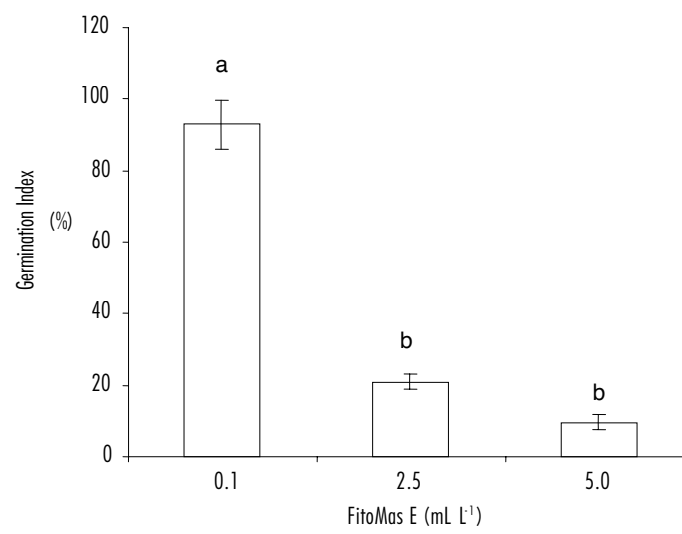

Figure 2. Influence of different concentrations of FitoMas E on germination index (GI) of Lactuca sativa seeds. Standard errors are indicated for each bar. Bars with the same letter are not statistically different $(\mathrm{P} \leq 0.05)$.

The reproducibility results of the assays are shown in Table 1. For a confidence level of $\mathrm{P} \leq 0.05$, the results indicated that there were no significant differences among the dishes and lots in all responses analyzed.

\section{Discussion}

\section{Effect of FitoMas E concentration}

The highest relative hypocotyl growth values were obtained with a FitoMas E concentration of $0.1 \mathrm{~mL} \mathrm{~L}^{-1}$, but these values decreased with higher concentrations of FitoMas E (2.5 and 5 $\mathrm{mL} \mathrm{L}^{-1}$ ). These results may be explained by the hormesis phenomenon, which is the relation between the dose and response, characterized by stimulation with low doses and inhibition with high doses (Calabrese and Baldwin, 2003).

Radicular stimulation in bioassays has been reported by others (Bohórquez and Campos, 2007); these authors obtained growth stimulation in two vegetal models using Lemna minor and Selenastrum capricornutum species in the evaluation of industrial effluents. The same authors attributed this effect to high concentrations of nitrogen and phosphorus, which are limited nutrients for many plants; this hypothesis is also applicable to the FitoMas E bionutrient because it has high nitrogen $\left(55 \mathrm{~mL} \mathrm{~L}^{-1}\right)$ and phosphorus $\left(31 \mathrm{~mL} \mathrm{~L}^{-1}\right)$ contents, including $\mathrm{P}_{2} \mathrm{O}_{5}$ (Montano et al., 2007). Bohórquez and Campos (2007) detected radicular stimulation by a bioassay using $L$. sativa seeds after they were exposed to water samples from different sources with high nitrogen and phosphorus contents.

In view of the stimulator effect induced by FitoMas E on different crop yields (Montano et al, 2007), it is convenient to perform the bioassay with lettuce seeds at the concentration where this effect is maintained as a quality indication, which is expressed mainly by the relative hypocotyl growth.

\section{Phytotoxicity test}

In this study, measurement of the germination index (GI) determined which studied FitoMas E concentrations caused phytotoxic effects. Several authors consider GI to be the most comprehensive indicator for describing the 
phytotoxic potential of organic matter (Varnero et al., 2007; Emino and Warman, 2004). Zucconi et al. (1981) suggested the following GI value classifications for phytotoxicity: GI values greater than or equal to $80 \%$ may indicate the absence or low concentrations of phytotoxic substances; GI values less than or equal to $50 \%$ may indicate a strong presence of phytotoxic substances; and GI values between 50 and $80 \%$ may indicate a moderate presence of these substances.

In this regard, the results obtained in this study (Figure 2) indicated that a FitoMas E concentration of $0.1 \mathrm{~mL} \mathrm{~L}^{-1}$ did not have a phytotoxic effect and that the FitoMas E concentrations of 2.5 and $5 \mathrm{~mL} \mathrm{~L}^{-1}$ had a high level of phytotoxicity.

\section{Reproducibility between FitoMas E lots and Petri dish replicates}

Because there were no significant differences between the lots and Petri dish replicates, it was important to verify the reproducibility of the results for different lots and dishes, which allowed this bioassay to be established as an in vitro assay method to be used as an indicator of FitoMas E quality.

This method allowed monitoring and control of the FitoMas E effects on the growth of model plants and potential phytotoxic effects produced by the FitoMas E lots.

The FitoMas E concentration of $0.1 \mathrm{~mL} \mathrm{~L}^{-1}$ allowed the determination of the stimulatory effect of this product without any phytotoxic effects by measuring the relative hypocotyl growth (RHG).

Measurements of the radicle and hypocotyl lengths were digitally performed with the Adobe Photoshop CS (Version 8.0.1) computer program, which allowed accurate and rapid results.

The bioassay method implemented in this study was rapid, simple and reliable, which allowed the quality of the FitoMas E product to be monitored and controlled.

\section{Resumen}

M.E. Díaz de Villegas, G. Delgado, M. Rivas, E. Torres y M. Saura. 2011. Implementación de un bioensayo in vitro como indicador de calidad del bionutriente FitoMas E. Cien. Inv. Agr. 38(2): 205-210. Los bioensayos con semillas se emplean para conocer el efecto estimulador de diferentes productos biológicos y para la detección y control de los contaminantes tóxicos ambientales. El presente trabajo, tuvo como objetivo, el diseño de un bioensayo in vitro, con semillas de lechuga, para llevar a cabo el seguimiento de la calidad de la producción final del FitoMas E, bionutriente derivado de la industria azucarera, producido por el Instituto Cubano de Investigaciones de Derivados de la Caña de Azúcar (ICIDCA), mediante la determinación de los índices de germinación y crecimiento de semillas de lechuga (Letucca sativa L.), como planta indicadora. Los efectos significativos de los factores controlables bajo estudio (concentración de FitoMas E, lotes y réplicas de las placas Petri), se determinaron mediante un análisis de varianza simple y multifactorial, para las siguientes variables: Porcentaje de germinación relativo (PRG), Crecimiento relativo de radícula (CRR), Crecimiento relativo de hipocotilo (RHG), e índice de germinación (IG). En todos los casos, los mayores valores de germinación relativa y crecimiento, se alcanzan a la concentración de $0,1 \mathrm{~mL} \mathrm{~L}^{-1}$, con un marcado incremento en el crecimiento del hipocótilo (RHG), que disminuyen a las concentraciones de 2,5 y $5 \mathrm{~mL} \mathrm{~L}^{-1}$, lo que puede explicarse por la existencia del fenómeno hormesis, caracterizada por estimulación a bajas dosis e inhibición con altas dosis. Para un nivel de confianza de $\mathrm{P} \leq 0,05$, los resultados obtenidos indicaron que no hay diferencias significativas entre las placas y los lotes en todas las respuestas analizadas. El método de bioensayo implementado, es rápido, sencillo y confiable.

Palabras clave: Bioensayo, bionutriente, semillas de lechuga. 


\section{References}

Bohórquez, P., and C. Campos. 2007. Evaluación de Lactuca sativa y Selenastrum capricornutum como indicadores de toxicidad en aguas. Universitas Scientiarum 12:83-98.

Calíbrese, E.J., and L.A. Baldwin. 2003. Hormesis: The Dose-Response Revolution. Annual Review of Pharmacology and Toxicology 43:175-197.

Díaz, T, A. Fernández, G. de Armas, and E. Sotomayor. 2002. Estimulador del crecimiento de origen vegetal: su efecto en el tomate (Lycopersicon esculentum Mill). Temas de Ciencia y Tecnología 6: $15-16$.

Emino, E., and P. Warman 2004. Biological assay for compost quality. Compost Science \& Utilization 12: 342-348.

Fernández-Larrea O. 2002. Control de calidad de los insecticidas microbianos. Manejo Integrado de Plagas y Agroecología (Costa Rica) 65:120-122.

Gariglio, N., M. Buyatte, R. Pilatti, D. Gonzalez Rossia, and M. Acosta. 2002. Use of a germination bioassay to test compost maturity of willow (Salix sp.) Sawdust. New Zealand Journal of Crop and Horticultural Science 30:135-139.

Keriko, J.M., S. Nakajima, N. Baba, Y. Isozaki, and J. Iwasa. 1995. Plant growth regulators from kenyan plant, Psiadia punctulata. Scientific reports of the Faculty of Agriculture Okayama University 84:7-11.

Montano R., R. Zuaznábar, A. García, M. Viñals, and J. Villar. 2007. FitoMas E Bionutriente Derivado de la Industria Azucarera. Revista ICIDCA sobre los Derivados de la Caña de Azúcar XLI: 14-21.

Navarro, A.R., R.G. Arrieta, and M.C. Maldonado. 2006. Determinación del efecto de diferentes compuestos a través de ensayos de fitotoxicidad usando semillas de lechuga, escarola y achicoria. Rev. Toxicol. 23:125-129.

Pennacchio M., L.V. Jefferson, and K. Havens. 2005. Arabidopsis thaliana: A new test species for phytotoxic bioassays. Journal of Chemical Ecology 31:1877-1885.

Sobrero M.C., and A. Ronco. 2004. Ensayo de toxicidad aguda con semillas de lechuga Lactuca sativa L. In: G. Castillo (ed.). Ensayos toxicológicos y métodos de evaluación de calidad de aguas. IDRC/ IMTA. Canadá, Capítulo 4. p. 71-79.

Tiquia, S.M. 2000. Evaluating phytotoxicity of pig manure from the pig on litter system. In: P.R. Warman and B.R. Taylor (eds.). Proceedings of the International Composting Symposium, CBA Press Inc.Truro, NS. p. 625-647.

Torres M.T. 2003. Empleo de los ensayos con plantas en el control de contaminantes tóxicos ambientales. Revista Cubana Higiene Epidemiología 41: 2-3.

Varnero M.T., C. Rojas, and R. Orellana. 2007. Índices de fitotoxicidad en residuos orgánicos durante el compostaje. Revista de la Ciencia del Suelo y Nutrición Vegetal 7: 28-37.

Zucconi, F., A Pera,. M.Forte, and M. De Bertoli. 1981. Evaluating toxicity in immature compost. Biocycle 22: 54-57. 